\title{
PŁEĆ JAKO DETERMINANTA SZANSY PODJĘCIA ZATRUDNIENIA I RYZYKA REZYGNACJI Z POŚREDNICTWA URZĘDU PRACY
}

\begin{abstract}
Streszczenie
Celem artykułu jest porównanie szans podjęcia pracy przez kobiety w stosunku do mężczyzn w zależności od wykształcenia i wieku. Ze względu na dużą liczbę osób rezygnujących z pośrednictwa urzędu w poszukiwaniu pracy, analizie poddano również ilorazy ryzyka tej rezygnacji przez kobiety w odniesieniu do mężczyzn w poszczególnych grupach wykształcenia i wieku. Przeprowadzone badanie miało na celu zweryfikowanie hipotezy, że bezrobotne kobiety były bardziej zdeterminowane do podjęcia pracy i częściej niż mężczyźni korzystały z ofert proponowanych przez urząd pracy. Do analizy wykorzystano dane ponad 20 tys. osób bezrobotnych, wyrejestrowanych w 2010 roku z Powiatowego Urzędu Pracy w Szczecinie.
\end{abstract}

Słowa kluczowe: bezrobocie, model logitowy, iloraz szans, iloraz ryzyka

\section{GENDER AS DETERMINANT OF EMPLOYMENT OPPORTUNITIES AND RISKS OF RESIGNING FROM SERVICES OF LABOUR OFFICE}

\section{Summary}

The purpose of this paper is to compare women's odds of employment to those of men's, depending on their education and age. Since a large number of people have rejected the services of Labour Offices, we also compare the odds ratios of the risk of this decision among women and men, according to education and age. The aim of the study was to verify the hypothesis that unemployed women were more determined to find a job and that they took into consideration their Labour Office offers more often than men. In the analysis we used the data on over 20,000 unemployed people who had deregistered from the Local Labour Office in Szczecin in 2010.

Key words: unemployment, logit model, odds ratio, risk ratio

\section{Wstęp}

W 2010 roku z Powiatowego Urzędu Pracy w Szczecinie zostało wyrejestrowanych ponad 20 tys. osób bezrobotnych. Przyczyny podawane przez urząd są bardzo szczegółowe i dotyczą między innymi: podjęcia pracy, wyjazdu za granicę, przejścia na eme-

1 dr Beata Bieszk-Stolorz - Wydział Nauk Ekonomicznych i Zarządzania, Uniwersytet Szczeciński; e-mail: stolorz@interia.pl; dr Iwona Markowicz - Wydział Nauk Ekonomicznych i Zarządzania, Uniwersytet Szczeciński; e-mail: imarkowicz@wneiz.pl. 
ryturę lub rentę, podjęcia nauki, niestawienia się w urzędzie. Ze względu na charakter urzędu, szczególne znaczenie przypisuje się podejmowaniu pracy przez osoby bezrobotne.

Celem artykułu jest porównanie szans podjęcia pracy przez kobiety w stosunku do mężczyzn w zależności od wykształcenia i wieku. Ze względu na dużą liczbę osób rezygnujących z pośrednictwa urzędu w poszukiwaniu pracy, analizie zostały poddane również ilorazy ryzyka tej rezygnacji przez kobiety w odniesieniu do mężczyzn w poszczególnych grupach wykształcenia i wieku.

Przeprowadzone badanie miało na celu zweryfikowanie hipotezy, że bezrobotne kobiety były bardziej zdeterminowane do podjęcia pracy i częściej niż mężczyźni korzystały z ofert proponowanych przez urząd pracy.

\section{Metodyka badania}

Rynek pracy jest obszarem wielu badań. Ich wyniki są prezentowane w licznych publikacjach naukowych i raportach. Jednym z czynników różnicującym sytuację osoby bezrobotnej jest jej płeć. W raporcie końcowym OECD z 2012 roku na temat równości płci w edukacji zatrudnienia i przedsiębiorczości stwierdza się, że w ostatnich latach udział kobiet w zatrudnieniu generalnie wzrósł, a nierówności płci w aktywności zawodowej zmniejszyły się [Gender..., 2012]. Mimo to segregacja zawodowa nie uległa poprawie. Nadal utrzymują się różnice w wynagrodzeniu kobiet i mężczyzn, a także kobiety są wciąż niedostatecznie reprezentowane na wyższych szczeblach zatrudnienia, zwłaszcza wśród menedżerów oraz w zarządach firm. Często pracują one w niepełnym wymiarze czasu, ponieważ ułatwia to łączenie obowiązków zawodowych i rodzinnych, ale jednocześnie wiąże się z utratą perspektyw na lepsze zarobki i rozwój kariery. Ponadto, we wszystkich krajach OECD kobiety częściej niż mężczyźni wykonują nieodpłatne prace (np. domowe). Podkreśla się, że dla zwiększenia poziomu zatrudnienia kobiet i osiagnięcia równości płci na rynku pracy jest niezbędne oficjalne wsparcie opieki nad dziećmi. Sytuacja kobiet na rynku pracy jest zdecydowanie lepsza w krajach wysoko rozwiniętych. Z raportu OECD wynika, że stopy bezrobocia w tych krajach w 2011 roku, liczone odrębnie dla każdej płci, są do siebie zbliżone (Belgia, Dania, Wegry, Izrael, Holandia, Szwecja, Republika Słowacka, Słowenia) lub nawet niższe dla kobiet (Kanada, Estonia, Finlandia, Niemcy, Islandia, Irlandia, Japonia, Korea, Norwegia, Wielka Brytania, USA).

Badania Sochy i Sztanderskiej wykazały, że zatrudnione kobiety rzadziej były narażone na bezrobocie, ale w przypadku utraty pracy znalazły się w dużo gorszej sytuacji niż mężczyźni, mimo korzystniejszych innych cech (np. lepszego wykształcenia), [Socha, Sztanderska, 2000]. Analiza szans na znalezienie zatrudnienia, przeprowadzona przez zespół: Daras i Jerzak, wskazała na ich ścisły związek z cechami demograficznymi badanych osób, takimi jak: płeć, wiek, wykształcenie, okres pozostawania bez pracy [Daras, Jerzak, 2005, s. 5-12]. Badanie zostało zrealizowane na podstawie danych pochodzacych $z$ ankiet BAEL w latach 1993-2003. Mniejsze szanse na znalezienie pracy miały kobiety, osoby poniżej 25 . i powyżej 45 . roku życia oraz osoby słabo wykształco- 
ne. Ze względu na funkcjonujące stereotypy, z powodu przerw w aktywności zawodowej (urodzenie i wychowywanie dzieci) kobiety w dalszym ciagu nie są wystarczająco konkurencyjne na rynku pracy wobec mężczyzn. Ich szanse na znalezienie pracy są nadal mniejsze, chociaż wykazują one większą aktywność w poszukiwaniu zatrudnienia. W ostatnich latach zauważa się zmianę modelu rodziny. Czynniki, takie jak: przesunięcie decyzji o urodzeniu dziecka, chęć usamodzielnienia się i uzyskania niezależności finansowej spowodowały wzrost aktywności zawodowej kobiet w wieku od 25 do 34 lat. Sztanderska i Grotkowska, porównując zatrudnienie i bezrobocie kobiet i mężczyzn, podkreślają wpływ faktu posiadania dzieci na zatrudnienie [Sztanderska, Grotkowska, 2007b]. Obecność w gospodarstwie domowym osób wymagających opieki, głównie dzieci w wieku do 3 lat, ale także w wieku przedszkolnym, kształtuje aktywność zawodową inaczej niż w gospodarstwach, w których ich nie ma - mężczyźni przeważnie zwiększają aktywność zawodowa, a kobiety ją ograniczają [Sztanderska, Grotkowska, 2007a]. Zatrudnienie kobiet w tym przypadku maleje przede wszystkim wskutek rezygnacji z aktywności zawodowej, a nie w wyniku nasilenia się trudności w uzyskaniu i utrzymaniu pracy. Jeśli istnieje możliwość zapewnienia zewnętrznej opieki nad małym dzieckiem, szczególnie nieodpłatnej, to zatrudnienie kobiet wyraźnie rośnie. Wykształcenie jest najsilniejszą determinantą zatrudnienia i bezrobocia kobiet, przy czym liczy się przeważnie jego poziom, a nie dziedzina. Kobiety o niższym poziomie wykształcenia mają mniejsze szanse na pracę i są bardziej zagrożone bezrobociem. Podobne rezultaty otrzymała Marcassa, która prowadziła badania nad czasem bezrobocia kobiet i mężczyzn we Francji w latach 1991-2002, ze szczególnym uwzględnieniem ich stanu cywilnego [Marcassa, 2011]. Wykazano, że w badanym okresie żonaci mężczyźni szybciej wychodzili z bezrobocia niż nieżonaci, a w przypadku kobiet sytuacja była odwrotna - mężatki miały mniejsze szanse na szybkie podjęcie zatrudnienia niż kobiety samotne ${ }^{2}$. Analizy wykonane przez zespół badaczy w: Rumunii, Austrii, Słowenii, Chorwacji i Macedonii wskazały, że płeć, wiek, poziom wykształcenia i region są determinantami czasu trwania bezrobocia [Kavkler, 2009]. Bezrobotni mężczyźni szybciej niż kobiety znajdowali zatrudnienie. Wyjątek stanowiła Austria, w której w latach 2000-2003 intensywność podjęcia pracy przez kobiety była aż o 33,7\% wyższa niż w przypadku mężczyzn.

Analizę przeprowadzono, wykorzystując dane 20846 osób wyrejestrowanych z Powiatowego Urzędu Pracy w Szczecinie w 2010 roku³. Wśród nich było 8679 kobiet, co stanowiło 41,6\% wszystkich bezrobotnych. Dane indywidualne zawierały informację o: płci, wieku, wykształceniu oraz przyczynie wyrejestrowania. Charakterystykę badanej zbiorowości przedstawiono w tabeli 1.

\footnotetext{
2 Zależność tę potwierdzają również badania opisane w pracach: [Foley, 1997; Tansel, Tasci, 2010].

${ }^{3}$ Badania przeprowadzono w ramach projektu badawczego: MNiSW, N, N111, 273538, finansowanego ze środków na naukę w latach 2010-2012.
} 
Charakterystyka badanej zbiorowości

\begin{tabular}{|c|c|c|c|c|c|c|}
\hline \multirow{2}{*}{ Cecha } & \multirow{2}{*}{ Grupy } & \multirow{2}{*}{$\begin{array}{c}\text { Liczebność } \\
\text { grupy }\end{array}$} & \multicolumn{2}{|c|}{$\begin{array}{l}\text { Podjęcie } \\
\text { pracy }\end{array}$} & \multicolumn{2}{|c|}{$\begin{array}{c}\text { Niepodjęcie } \\
\text { pracy (w tym odmowa) }\end{array}$} \\
\hline & & & liczba & odsetek & liczba & odsetek \\
\hline \multirow{2}{*}{$\frac{u}{\tilde{Z}}$} & kobiety & 8679 & 4227 & 48,70 & $\begin{array}{c}4452 \\
(3466)\end{array}$ & $51,30(39,94)$ \\
\hline & mężczyźni & 12167 & 4913 & 40,38 & $\begin{array}{c}7254 \\
(6329)\end{array}$ & $59,62(52,02)$ \\
\hline \multirow{5}{*}{ 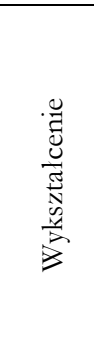 } & co najwyżej gimnazjalne & 6054 & 1634 & 26,99 & $\begin{array}{c}4420 \\
(3960)\end{array}$ & $73,01(65,41)$ \\
\hline & zasadnicze zawodowe & 4558 & 1933 & 42,41 & $\begin{array}{c}2625 \\
(2286)\end{array}$ & $57,59(50,15)$ \\
\hline & średnie ogólnokształcące & 2337 & 972 & 41,59 & $\begin{array}{c}1365 \\
(1129)\end{array}$ & $58,41(48,31)$ \\
\hline & $\begin{array}{l}\text { średnie zawodowe, poma- } \\
\text { turalne, policealne }\end{array}$ & 3783 & 1863 & 49,25 & $\begin{array}{c}1920 \\
(1510) \\
\end{array}$ & $50,75(39,92)$ \\
\hline & wyższe & 4114 & 2738 & 66,55 & $\begin{array}{l}1376 \\
(910)\end{array}$ & $33,45(22,12)$ \\
\hline \multirow{6}{*}{ 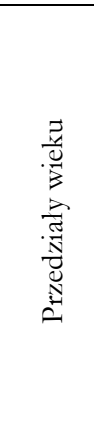 } & $18-24$ & 3555 & 1100 & 30,94 & $\begin{array}{c}2455 \\
(2178) \\
\end{array}$ & $69,06(61,27)$ \\
\hline & $25-34$ & 7823 & 3770 & 48,19 & $\begin{array}{c}4153 \\
(3568)\end{array}$ & $53,09(45,61)$ \\
\hline & $35-44$ & 3750 & 1768 & 47,15 & $\begin{array}{c}1982 \\
(1719)\end{array}$ & $52,85(45,84)$ \\
\hline & $45-54$ & 3585 & 1716 & 47,87 & $\begin{array}{c}1869 \\
(1548)\end{array}$ & $52,13(43,18)$ \\
\hline & $55-59$ & 1597 & 682 & 42,71 & $\begin{array}{c}915 \\
(615)\end{array}$ & $57,29(38,51)$ \\
\hline & 60 i więcej & 436 & 104 & 23,85 & $\begin{array}{c}332 \\
(167)\end{array}$ & $76,15(38,30)$ \\
\hline
\end{tabular}

Źródło: opracowanie własne na podstawie danych PUP w Szczecinie.

Do zbadania ilorazów szans podjęcia zatrudnienia i ilorazów ryzyka rezygnacji z pośrednictwa urzędu wykorzystano model logitowy. W związku z tym, że zmienna objaśniana jest dychotomiczna, zastosowano dwumianowy model logitowy [Hosmer, Lemeshow, 2000; Kleinbaum, Klein, 2002]. Postać logistyczna tego modelu jest następująca:

$$
P\left(Y=1 \mid x_{1}, x_{2}, \ldots, x_{m}\right)=\frac{\exp \left(\alpha_{0}+\sum_{i=1}^{m} \alpha_{i} x_{i}\right)}{1+\exp \left(\alpha_{0}+\sum_{i=1}^{m} \alpha_{i} x_{i}\right)},
$$

gdzie:

$Y$ - zmienna objaśniana przyjmująca wartość 1, gdy zachodzi określone zdarzenie, wartość 0 , gdy zdarzenie nie zaszło, 
$x_{i}$ - zmienne objaśniające dla $i=1,2, \ldots, m$, $a_{0}, a_{i}$ - parametry modelu dla $i=1,2, \ldots, m$.

Po zlogarytmowaniu (1) otrzymuje się postać logitową modelu, określoną wzorem:

$$
\operatorname{logit}(p)=\ln \left(\frac{p}{1-p}\right)=\alpha_{0}+\sum_{i=1}^{m} \alpha_{i} x_{i},
$$

gdzie:

$p=P\left(Y=1 \mid x_{1}, x_{2}, \ldots, x_{m}\right)-$ prawdopodobieństwo zajścia zdarzenia.

Do interpretacji wyników wykorzystuje się wyrażenie $\exp \left(a_{i}\right)$, będące ilorazem szans $(O R)$ lub ryzyka $(R R)$ na zajście zdarzenia w danej grupie w stosunku do grupy porównywanej. Ilorazy szans lub ryzyka wskazują na wyższe $-O R(R R)>1-$ lub niższe $O R(R R)<1$ - szanse albo ryzyko zajścia określonego zdarzenia w danej grupie w stosunku do innej grupy. Stąd konieczność ustalenia grupy odniesienia i odpowiedniego zakodowania wariantów zmiennych objaśniających.

Zbudowano dwa rodzaje modeli dwumianowych, w których zmienną objaśniająca jest płeć $P$, przyjmująca wartość 1 dla kobiet i 0 dla mężczyzn (grupa odniesienia):

$$
\operatorname{logit}(p)=\alpha_{0}+\alpha_{1} P \text {. }
$$

W pierwszym rodzaju modeli badanym zdarzeniem było podjęcie zatrudnienia (szansa podjęcia zatrudnienia), a w drugim - wyrejestrowanie osoby bezrobotnej z powodu: odmowy przyjęcia pracy, braku gotowości do podjęcia pracy lub niestawienia się w urzędzie w wyznaczonym terminie (ryzyko wyrejestrowania z urzędu bez uzyskania oferty pracy). Oba rodzaje modeli szacowano dla wszystkich wyrejestrowanych bezrobotnych ogólem oraz w poszczególnych grupach wykształcenia i wieku. Oceny parametrów we wszystkich modelach były istotne statystycznie. Świadczą o tym wartości $p<0,05$ zarówno dla testu $\chi^{2}$, weryfikującego istotność wszystkich parametrów modeli poza wyrazem wolnym, jak i dla testu Walda weryfikującego istotność poszczególnych parametrów.

\section{Ocena wpływu płci osób bezrobotnych na szansę podjęcia zatrudnienia i ryzyko wyrejestrowania bez uzyskania oferty pracy}

W Szczecinie w 2010 roku, na 20846 osób wyrejestrowanych z Powiatowego Urzędu Pracy, 9140 to osoby, które podjęły zatrudnienie. Przyjęto następujące formy zatrudnienia: podjęcie pracy, podjęcie działalności gospodarczej, podjęcie pracy w ramach refundacji kosztów zatrudnienia bezrobotnego, podjęcie pracy w ramach prac interwencyjnych oraz podjęcie pracy w ramach robót publicznych. Wśród nich było 4227 kobiet $(48,70 \%)$, natomiast 11706 osób zostało wyrejestrowanych z innych powodów niż podjęcie pracy. Część z nich: przeszła na emeryturę lub rentę, otrzymała zasiłek przedemerytalny albo świadczenie rehabilitacyjne, rozpoczęła naukę, zadeklarowała wyjazd za granicę, zmieniła miejsce zamieszkania. Jednak bardzo dużo osób (9795) zrezygnowało z pośrednictwa urzędu w poszukiwaniu pracy. Wyrejestrowanie tych osób nastąpiło z powodu: odmowy przyjęcia pracy, braku gotowości do podjęcia pracy bądź niestawienia się w urzędzie w wyznaczonym terminie. Są to powody wskazujące na: brak zaintere- 
sowania ofertami pracy proponowanymi przez urząd, niechęć do podjęcia zatrudnienia, podjęcie zatrudnienia w ,,szarej strefie” lub samodzielne znalezienie pracy. W tej grupie osób udział kobiet był mniejszy i wynosił 39,94\%.

Wykorzystując modele logitowe pierwszego rodzaju (tabela 2.), uzyskano ilorazy szans podjęcia zatrudnienia przez kobiety w stosunku do mężczyzn (rysunek 1.). Iloraz szans dla kategorii odniesienia (w badaniu są to mężczyźni) przyjmuje wartość 1, co oznaczono linią na rysunkach: 1. i 2.

TABELA 2.

Wyniki szacowania modeli logitowych podjęcia zatrudnienia przez bezrobotne kobiety w stosunku do bezrobotnych mężczyzn ogółem i według poziomu wykształcenia i grup wieku

\begin{tabular}{|c|c|c|c|c|c|}
\hline Zmienne & $\begin{array}{c}\text { Ocena para- } \\
\text { metru }\end{array}$ & $\begin{array}{c}\text { Odchylenie } \\
\text { standardowe }\end{array}$ & $\begin{array}{c}\text { Statystyka } \\
\text { Walda }\end{array}$ & $p$ & $O R$ \\
\hline \multicolumn{6}{|c|}{ Ogółem } \\
\hline Wyraz wolny & $-0,3897$ & 0,0185 & 444,7655 & 0,0000 & \\
\hline Płeć & 0,3378 & 0,0283 & 142,1821 & 0,0000 & 1,4019 \\
\hline \multicolumn{6}{|c|}{ Wykształcenie co najwyżej gimnazjalne } \\
\hline Wyraz wolny & $-1,0336$ & 0,0360 & 822,7731 & 0,0000 & \\
\hline Płeć & 0,1106 & 0,0606 & 3,3359 & 0,0678 & 1,1169 \\
\hline \multicolumn{6}{|c|}{ Wykształcenie zasadnicze zawodowe } \\
\hline Wyraz wolny & $-0,3159$ & 0,0351 & 81,1011 & 0,0000 & \\
\hline Płeć & 0,0368 & 0,0675 & 0,2972 & 0,5856 & 1,0375 \\
\hline \multicolumn{6}{|c|}{ Wykształcenie średnie ogólnokształcące } \\
\hline Wyraz wolny & $-0,5173$ & 0,0632 & 67,0637 & 0,0000 & \\
\hline Płeć & 0,3240 & 0,0847 & 14,6191 & 0,0001 & 1,3826 \\
\hline \multicolumn{6}{|c|}{ Wykształcenie średnie zawodowe, pomaturalne, policealne } \\
\hline Wyraz wolny & $-0,1258$ & 0,0434 & 8,4032 & 0,0037 & \\
\hline Płeć & 0,2192 & 0,0657 & 11,1417 & 0,0008 & 1,2451 \\
\hline \multicolumn{6}{|c|}{ Wykształcenie wyższe } \\
\hline Wyraz wolny & 0,5948 & 0,0514 & 133,8211 & 0,0000 & \\
\hline Płeć & 0,1574 & 0,0671 & 5,4982 & 0,0190 & 1,1705 \\
\hline \multicolumn{6}{|c|}{ Wiek: $18-24$ lata } \\
\hline Wyraz wolny & $-1,0325$ & 0,0513 & 405,6528 & 0,0000 & \\
\hline Pleć & 0,4887 & 0,0730 & 44,7680 & 0,0000 & 1,6302 \\
\hline \multicolumn{6}{|c|}{ Wiek: 25-34 lata } \\
\hline Wyraz wolny & $-0,3295$ & 0,0309 & 113,4354 & 0,0000 & \\
\hline Płeć & 0,5052 & 0,0455 & 123,4265 & 0,0000 & 1,6573 \\
\hline \multicolumn{6}{|c|}{ Wiek: 35-44 lata } \\
\hline Wyraz wolny & $-0,2489$ & 0,0426 & 34,1234 & 0,0000 & \\
\hline Płeć & 0,3323 & 0,0668 & 24,7283 & 0,0000 & 1,3941 \\
\hline \multicolumn{6}{|c|}{ Wiek: 45-54 lata } \\
\hline Wyraz wolny & $-0,1520$ & 0,0428 & 12,6467 & 0,0004 & \\
\hline Płeć & 0,1723 & 0,0687 & 6,2899 & 0,0121 & 1,1880 \\
\hline \multicolumn{6}{|c|}{ Wiek: 54-59 lat } \\
\hline Wyraz wolny & $-0,1837$ & 0,0605 & 9,2225 & 0,0024 & \\
\hline Płeć & $-0,3641$ & 0,1113 & 10,7084 & 0,0011 & 0,6949 \\
\hline
\end{tabular}

$p-$ poziom istotności parametru

OR - iloraz szans

Źródło: opracowanie własne z wykorzystaniem programu STATISTICA. 
RYSUNEK 1.

Ilorazy szans $(O R)$ podjęcia zatrudnienia przez bezrobotne kobiety w stosunku do bezrobotnych mężczyzn ogółem, w grupach wykształcenia i wieku

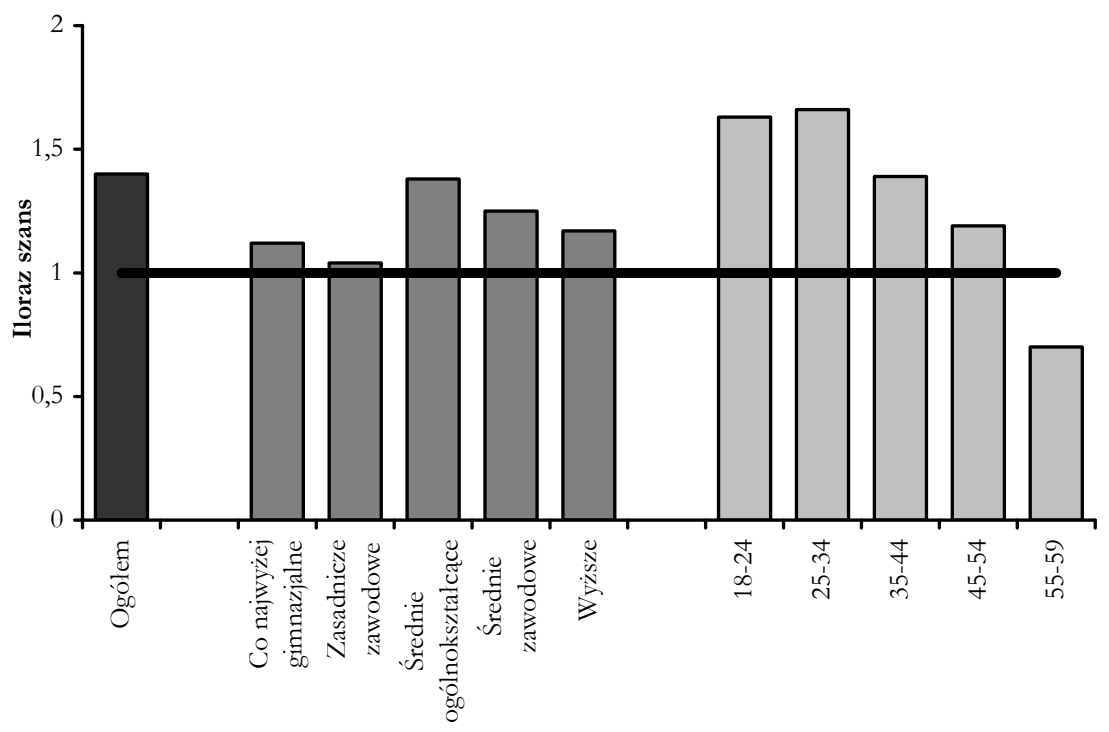

Źródło: opracowanie własne na podstawie danych z tabeli 2.

Podjęcie pracy było częstszą przyczyną wyrejestrowania w przypadku kobiet niż mężczyzn - o 40\% (iloraz szans równy 1,4)4. Analizując poszczególne grupy wykształcenia, należy stwierdzić, że omówiona prawidłowość wystapiła na każdym poziomie wykształcenia (ilorazy szans większe od 1). Największa dysproporcja była zauważalna w przypadku osób o wykształceniu średnim ogólnokształcącym. W tej grupie kobiety o 38\% częściej wychodziły z bezrobocia. W poszczególnych grupach wieku szansa podjęcia pracy przez kobiety była większa niż przez mężczyzn. Wyjątek stanowily osoby bezrobotne w wieku od 55 do 59 lat, wśród których to mężczyźni mieli większe szanse na zatrudnienie (iloraz szans równy 0,69$)$. Kobiety bezrobotne z tej grupy są niechętnie zatrudniane przez pracodawców, więc mają niskie szanse na powrót do pracy, dlatego też korzystają często z zasiłków przedemerytalnych. W przeciwnej sytuacji są kobiety młode (do 35. roku życia), które o ponad 60\% częściej niż mężczyźni podejmowały pracę.

Druga grupa modeli logitowych (tabela 3.) umożliwiła uzyskanie wartości ilorazów ryzyka wyrejestrowania z urzędu pracy z przyczyn leżących po stronie bezrobotnego (rysunek 2.). Powody wyrejestrowania w tym przypadku świadczą o braku zainteresowania ofertami pracy proponowanymi przez urząd.

\footnotetext{
${ }^{4}$ Z wcześniejszych badań autorek wynika, że szanse kobiet w 2008 roku były większe o 47\% [Markowicz, Stolorz, 2009].
} 
TABELA 3.

Wyniki szacowania modeli logitowych rezygnacji z pośrednictwa urzędu pracy przez bezrobotne kobiety w stosunku do bezrobotnych mężczyzn ogółem i według poziomu wykształcenia i grup wieku

\begin{tabular}{|c|c|c|c|c|c|}
\hline Zmienne & $\begin{array}{c}\text { Ocena para- } \\
\text { metru }\end{array}$ & $\begin{array}{l}\text { Odchylenie } \\
\text { standardowe }\end{array}$ & $\begin{array}{c}\text { Statystyka } \\
\text { Walda }\end{array}$ & $p$ & $R R$ \\
\hline \multicolumn{6}{|c|}{ Ogółem } \\
\hline Wyraz wolny & 0,0808 & 0,0181 & 19,8036 & 0,0000 & \\
\hline Płeć & $-0,4889$ & 0,0285 & 295,2319 & 0,0000 & 0,6133 \\
\hline \multicolumn{6}{|c|}{ Wykształcenie co najwyżej gimnazjalne } \\
\hline Wyraz wolny & 0,7003 & 0,0337 & 432,6228 & 0,0000 & \\
\hline Płeć & $-0,1810$ & 0,0565 & 10,2563 & 0,0014 & 0,8344 \\
\hline \multicolumn{6}{|c|}{ Wykształcenie zasadnicze zawodowe } \\
\hline Wyraz wolny & 0,0564 & 0,0347 & 2,6512 & 0,1035 & \\
\hline Płeć & $-0,1871$ & 0,0669 & 7,8198 & 0,0052 & 0,8293 \\
\hline \multicolumn{6}{|c|}{ Wykształcenie średnie ogólnokształcące } \\
\hline Wyraz wolny & 0,1703 & 0,0613 & 7,7134 & 0,0055 & \\
\hline Płeć & $-0,4405$ & 0,0835 & 27,8062 & 0,0000 & 0,6437 \\
\hline \multicolumn{6}{|c|}{ Wykształcenie średnie zawodowe, pomaturalne, policealne } \\
\hline Wyraz wolny & $-0,2069$ & 0,0435 & 22,5997 & 0,0000 & \\
\hline Płeć & $-0,4771$ & 0,0679 & 49,3288 & 0,0000 & 0,6206 \\
\hline \multicolumn{6}{|c|}{ Wykształcenie wyższe } \\
\hline Wyraz wolny & $-1,0785$ & 0,0566 & 363,6944 & 0,0000 & \\
\hline Płeć & $-0,3118$ & 0,0758 & 16,9349 & 0,0000 & 0,7321 \\
\hline \multicolumn{6}{|c|}{ Wiek: 18-24 lata } \\
\hline Wyraz wolny & 0,7580 & 0,0484 & 245,2912 & 0,0000 & \\
\hline Płeć & $-0,6447$ & 0,0698 & 85,4036 & 0,0000 & 0,5248 \\
\hline \multicolumn{6}{|c|}{ Wiek: $25-34$ lata } \\
\hline Wyraz wolny & 0,0890 & 0,0306 & 8,4922 & 0,0036 & \\
\hline Płeć & $-0,6415$ & 0,0461 & 193,9646 & 0,0000 & 0,5265 \\
\hline \multicolumn{6}{|c|}{ Wiek: 35-44 lata } \\
\hline Wyraz wolny & 0,0206 & 0,0423 & 0,2365 & 0,6268 & \\
\hline Płeć & $-0,4708$ & 0,0676 & 48,5296 & 0,0000 & 0,6245 \\
\hline \multicolumn{6}{|c|}{ Wiek: $45-54$ lata } \\
\hline Wyraz wolny & $-0,1466$ & 0,0427 & 11,7559 & 0,0006 & \\
\hline Płeć & $-0,3366$ & 0,0699 & 23,1751 & 0,0000 & 0,7142 \\
\hline \multicolumn{6}{|c|}{ Wiek: 55-59 lat } \\
\hline Wyraz wolny & $-0,4024$ & 0,0614 & 42,9002 & 0,0000 & \\
\hline Płeć & $-0,2157$ & 0,1126 & 3,6721 & 0,0553 & 0,8060 \\
\hline
\end{tabular}

$p-$ poziom istotności parametru

$\mathrm{RR}$ - iloraz ryzyka

Źródło: opracowanie własne z wykorzystaniem programu STATISTICA.

Wyrejestrowanie bezrobotnych z powodu odmowy przyjęcia pracy, braku gotowości do jej podjęcia lub niestawienia się w wyznaczonym terminie było rzadsze o 39\% w przypadku kobiet niż mężczyzn (iloraz ryzyka równy 0,61). Tendencja ta była widoczna we wszystkich grupach wieku i wykształcenia (wszystkie ilorazy ryzyka mniejsze od 1). Największym ryzykiem wyrejestrowania bez podjęcia pracy charakteryzowały się kobiety z wykształceniem co najwyżej gimnazjalnym i zasadniczym zawodowym, ale i tak było ono mniejsze o około $17 \%$ w porównaniu z analogicznymi grupami mężczyzn. W przypadku grup wieku, kobiety w wieku przedemerytalnym częściej niż w pozosta- 
łych grupach rezygnowały z pośrednictwa urzędu pracy (jednak o około $20 \%$ rzadziej niż mężczyźni).

RYSUNEK 2. Ilorazy ryzyka $(R R)$ wyrejestrowania bez uzyskania oferty pracy przez bezrobotne kobiety w stosunku do bezrobotnych mężczyzn ogółem, w grupach wykształcenia i wieku

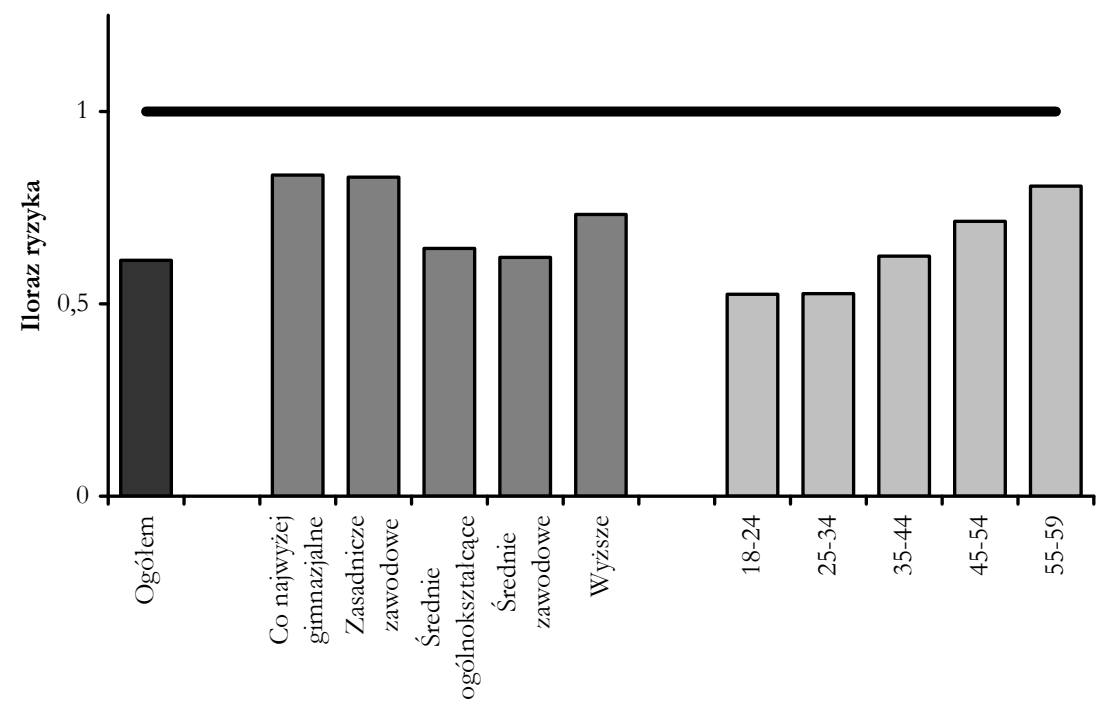

Źródło: opracowanie własne na podstawie danych z tabeli 3.

\section{Podsumowanie}

Zastosowanie dwumianowego modelu logitowego posłużyło ocenie wpływu płci osób bezrobotnych na możliwość podjęcia zatrudnienia. Przeprowadzone badanie pozwoliło na zweryfikowanie hipotezy, że bezrobotne kobiety w Szczecinie w 2010 roku były bardziej zdeterminowane do podjęcia pracy i częściej niż mężczyźni korzystały $z$ ofert proponowanych przez urząd pracy. Wyrejestrowanie kobiet następowało częściej z powodu podjęcia pracy (o $40 \%$ niż w przypadku mężczyzn) i rzadziej rezygnowały one ze współpracy z urzędem (o 39\% niż w przypadku mężczyzn). Wniosek taki dotyczy wszystkich bezrobotnych ogółem oraz bezrobotnych w poszczególnych grupach wykształcenia i wieku. Pozyskane dane statystyczne wskazują na to, że w badanym okresie w Szczecinie kobiety częściej dopełniały formalności związanych z wyrejestrowaniem się z urzędu, podając powód. Natomiast mężczyźni częściej byli wyrejestrowywani przez urząd pracy z powodu niestawienia się w określonym terminie. Należy zauważyć, że zarówno wśród kobiet, jak i mężczyzn udział osób rezygnujących z pośrednictwa pracy ma- 
lał wraz ze wzrostem poziomu wykształcenia oraz wieku. Zatem, osoby młode i słabo wykształcone rzadziej podejmowały zatrudnienie, korzystając z propozycji urzędu pracy.

Rezygnacja mężczyzn z pośrednictwa urzędu pracy w Szczecinie może wynikać z większych możliwości uzyskania zarobku z pracy „na czarno” (często są to proste prace fizyczne w budownictwie), a także łatwiejszego decydowania o wyjeździe za granicę do pracy na jakiś czas (kobietom przychodzi to trudniej ze względu na obowiazki rodzinne, szczególnie opiekę nad dziećmi). Większe szanse kobiet na podjęcie zatrudnienia oferowanego przez urząd pracy są rezultatem między innymi mniejszych wymagań płacowych. Unia Europejska w ramach prowadzonej polityki społecznej i zatrudnienia dąży do wyrównania szans zawodowych obu płci w celu: poprawy jakości i efektywności pracy, wzmocnienia konkurencyjności, zwiększenia liczby miejsc pracy i zapewnienia równego do nich dostępu.

\section{Literatura}

Bieszk-Stolorz B., Markowicz I. 2011 Ocena szansy uyjśsia z. bezrobocia ze wagledu na wiek i stażpracy berrobotnych zarejestrowanych w PUP w S zrzecinie, ,Taksonomia 18. Klasyfikacja i analiza danych - teoria i zastosowania", Prace Naukowe Uniwersytetu Ekonomicznego we Wrocławiu nr 176, Wrocław.

Daras T., Jerzak M. 2005 Wphyw cech społeczno-demograficznych osób bezrobotnych na możliwośt znalerienia pracy, badanie na podstawie danych BAEL w latach 1993-2003, Materiały i Studia, Zeszyt nr 189, NBP, Warszawa.

Foley M.C., Determinants of unemployment duration In Russia, Working Paper nr 81, The William Davidson Institute AT the Univeristy of Michigan Business School 1997, dokument elektroniczny, tryb dostępu: [http://www.wdi.umich.eduęfilesęPubli cationsęWorkingPapersęwp81.pdf, data wejścia: 15.12.2012].

Gender Equality in Education, Employment and Entrepreneurship: Final Report to the C/MIN(2012)5, Meeting of the OECD Council at Ministerial Level, Paris 2012, dokument elektroniczny, tryb dostępu: [http://www.oecd.org/social/familiesandchildren/ 50423364.pdf, data wejścia: 18.12.2012].

Hosmer D.W., Lemeshow S. 2000 Applied Logistic Regression, John Wiley \& Sons, Inc., New York.

Kavkler A., Danacica D.E., Babucea A.G., Bicanic I., Bohm B., Tevdovski D., Tosevska K., Borsic D. 2009 Cox Regression Models for Unemployment Duration in Romania, Austria, Slovenia, Croatia, and Macedonia, „Romanian Journal of Economic Forecasting", vol. 10, isssue 2.

Kleinbaum D.G., Klein M. 2002 Logistic Regression. A Self-Lerning Text, Springer-Verlag, New York.

Marcassa S. 2011 Unemployment Duration of Spouses: Evidence From France, THEMA Working Papers 2012-31, THEMA (THéorie Economique, Modélisation et Applications), Université de Cergy-Pontoise.

Markowicz I., Stolorz B. 2009 Wplyw sposobu kodowania zmiennych na interpretacjeparametrón modelu regresji logistycznej, „Modelowanie i prognozowanie gospodarki narodowej”, Prace 
i Materiały Wydziału Zarządzania Uniwersytetu Gdańskiego, Wydział Zarządzania Uniwersytetu Gdańskiego, nr 4/2, Fundacja Rozwoju Uniwersytetu Gdańskiego, Sopot.

OECD Harmonised Unemployment Rates, News Release: August 2012, Paryż, dokument elektroniczny, tryb dostępu: [http://www.oecd.org/std/labourstatistics/HUR_ NR10e12.pdf, data wejścia: 20.12.2012].

Socha M., Sztanderska U. 2000 Strukturalne podstany bezrobocia w Polsce, Wydawnictwo Naukowe PWN, Warszawa.

Sztanderska U., Grotkowska G. 2007a Aktywność ekonomiczna ludności, [w:] Aktymność zawodowa i edukacyjna a obowiazki rodzinne w Polsce w swietle badan empirycznych, I. E. Kotowska, U. Sztanderska, I. Wóycicka (red.), Wydawnictwo Naukowe SCHOLAR, Warszawa.

Sztanderska U., Grotkowska G. 2007b Zatrudnienie i bearobocie kobiet i mę̇çyzn, [w:] Aktywnośc zawodowa $i$ edukacyjna a obowiazki rodzinne w Polsce w swietle badań empirycznych, I. E. Kotowska, U. Sztanderska, I. Wóycicka (red.), Wydawnictwo Naukowe SCHOLAR, Warszawa.

Tansel A., Tasci H.M. 2010 Hazard Analysis of Unemployment Duration by Gender In Developing Country: The Case of Turkey, Labour 24(4). 